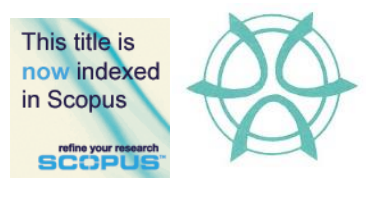

PLANNING MALAYSIA:

Journal of the Malaysian Institute of Planners

VOLUME 16 ISSUE 1 (2018), Page 193 - 204

\title{
FACTORS INFLUENCING THE WILLINGNESS TO WALK TO THE BUS STOPS IN PENANG ISLAND
}

\author{
Nur Sabahiah Abdul Sukor ${ }^{1} \&$ Siti Fadhlina Muhammad Fisal ${ }^{2}$ \\ ${ }^{1,2}$ School of Civil Engineering \\ UNIVERSITI SAINS MALAYSIA
}

\begin{abstract}
This study, investigates pedestrians' 'willingness to walk' to Rapid Penang bus stops in Penang Island. Parameters, such as socio-demographics, walking distance and walking time, were examined to determine factors that influence 'willingness to walk'. Questionnaire surveys were used to collect the data from 400 participants. The data was analysed using multiple regression analysis through the 'Statistical Package for the Social Sciences' (SPSS). Analysis of determinant factors was split into two dependent variables. Firstly, the willingness to walk based on current condition, and secondly, the willingness to walk, if improvements to environment and infrastructure were made to the bus stops. The results showed that socio-demographic factors, such as walking distance, walking time and trip purpose would likely to influence the pedestrians' 'willingness to walk'. This study also identified the maximum, minimum, and average distances walked by a pedestrian to reach the bus stops (as well as the willingness travel time.) The outcome of this study will contribute to better planning of transportation system in Penang Island especially on the Penang Transport Master Plan (PTMP) projects.
\end{abstract}

Keyword: pedestrian, willingness to walk, walking distance, walking time, public bus service 
Nur Sabahiah Abdul Sukor \& Siti Fadhlina Muhammad Fisal

Factors Influencing the Willingness to Walk to the Bus Stops in Penang Island

\section{INTRODUCTION}

To achieve sustainable city status, Penang State Government has focused on three issues, crime, cleanliness and traffic congestion ("Penang Transport Master Plan", 2013). Penang State Government, through continuous effort, has delivered praiseworthy progress; the crime rate has decreased and the environment has seen some regeneration. However, traffic congestion remains a primary concern on Penang Island, due to economic growth and increasing numbers of tourists.

In 2013 the Transport Master Plan Strategy report, was adopted by Penang State Government in a bid to improve the transport system (Pejabat Setiausaha Kerajaan Negeri Pulau Pinang, 2013). The strategy outlines an integrated transit network, with the appropriate long-term capacity to increase public transport adaptation in Penang. The proposed transit lines are Bayan Lepas LRT, Ayer Itam monorail, Tanjung Tokong monorail, and tram services in the Georgetown heritage area. However, this study focuses on the Bayan Lepas LRT network from Kompleks Tun Abdul Razak (KOMTAR), to land considered most suitable for reclamation in the south, made up of 27 stations along a 30-km length network, as shown in Figure 1.

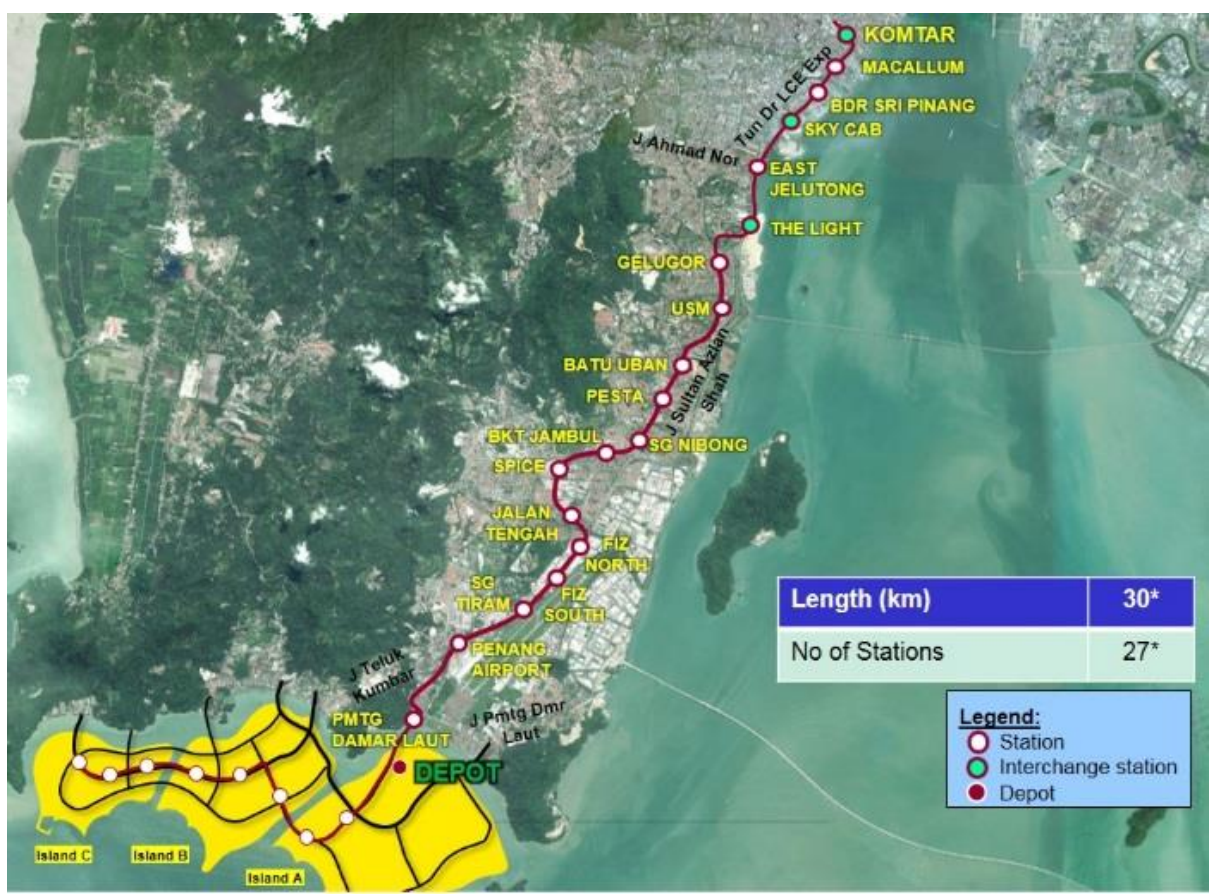

Figure 1: Proposed network of Bayan Lepas LRT line Source: http://pgmasterplan.penang.gov.my 
PLANNING MALAYSIA

Journal of the Malaysia Institute of Planners (2018)

Links between future development of Bayan Lepas LRT and Rapid Penang bus routes have been investigated, finding Route 303 from Weld Quay Port to Persiaran Mayang Pasir to be the most parallel. Consequently, the study of walking accessibility to public transport was done on Route 303, which is expected to support accessibility to the proposed LRT lines. The Rapid Penang bus route is shown in Figure 2.

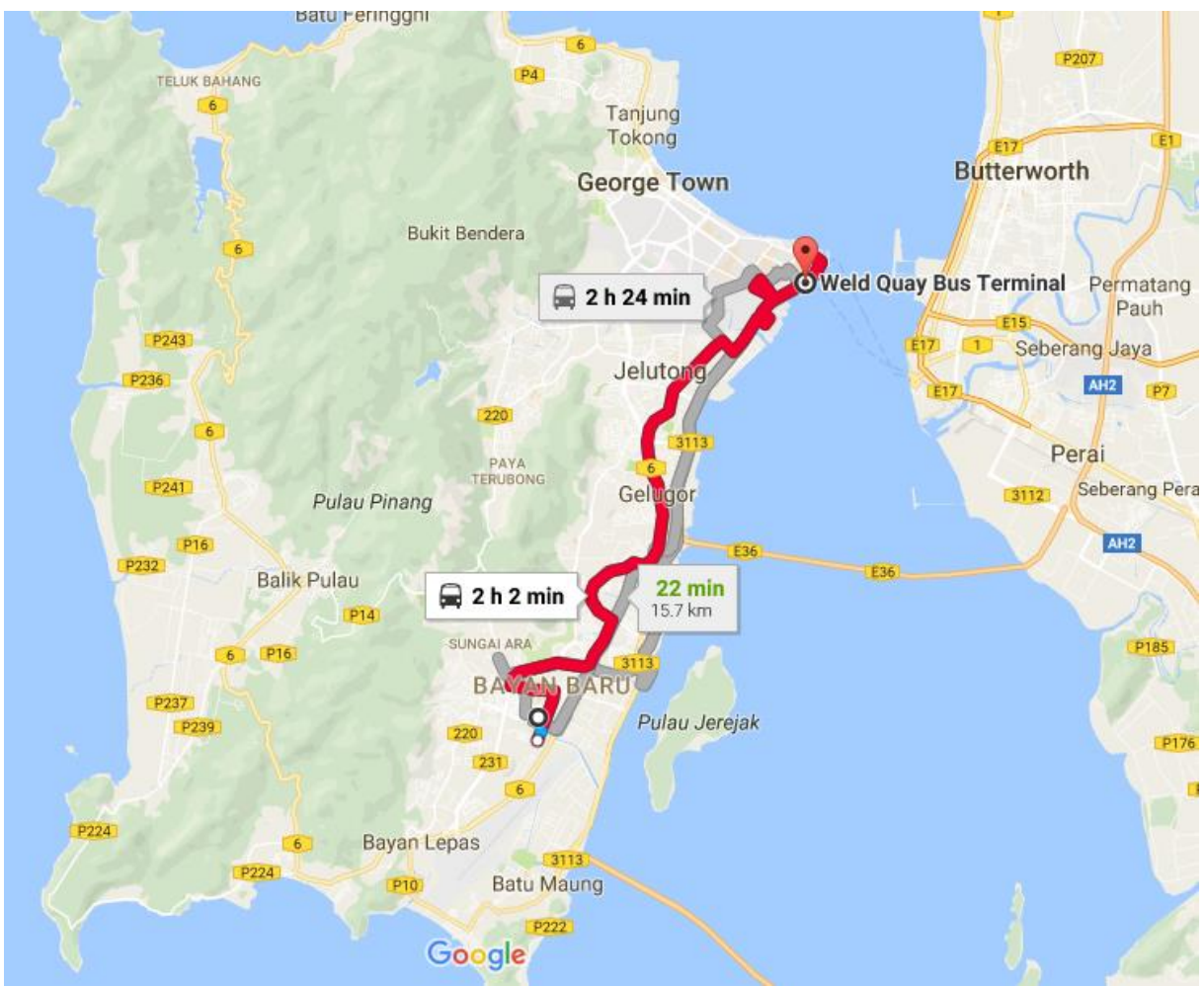

Figure 2: 303 Rapid Bus route

Source: https://www.google.com/maps. Rapid Penang Route 303

To gain insight on accessibility to the proposed transit network, the primary objective of this research is to identify acceptable walking distances to bus stops, while taking the origin and destination of pedestrians into consideration. The second objective is to analyse factors that affect a bus users' 'willingness to walk'.

\section{RESEARCH BACKGROUND}

This subtopic briefly explains factors that affect 'willingness to walk', as found in previous studies. Socio-demographics, such as walking distance, satisfaction level, and infrastructure conditions are all sighted. 
Nur Sabahiah Abdul Sukor \& Siti Fadhlina Muhammad Fisal

Factors Influencing the Willingness to Walk to the Bus Stops in Penang Island

Daniels and Mulley (2013) claim that the impact of socio-demographic factors, has mostly been studied in the context of differentiating factors for 'willingness to walk', and travel behaviour. Gender, age, marital status, income; education, and vehicle ownership were all factors. Corpuz, Hay, \& Merom (2005) find that females in Sydney walked more than their male counterparts, those older and younger in age walked more, as did people with low car ownership. Moreover, Freeland, Banerjee, Dannenberg and Wendel (2013) state that those from lower income households, living in urban environments with greater access to public transport, were likely to walk more.

In addition, Burke and Brown (2007) used travel data collected from the 'single weekday travel diaries' of 10,931 Queensland residents, which included trips to schools, workplaces and shops. The study found $600 \mathrm{~m}$ to be the average walking distance between homes and local public transport. Meanwhile, analysis of travel data from Sydney found that bus users walked for $50 \mathrm{~m}$ to access bus services, while train users were willing to walk distances greater than $100 \mathrm{~m}$ to access train services. The studies showed a marked difference in average walking distances, between users of train and bus services. Findings showed train users were willing to walk up to $2,000 \mathrm{~m}$ to access services, while those using bus services were only willing to walk up to $1,900 \mathrm{~m}$ (Daniels \& Mulley, 2013).

In addition, Owen, Humpel, Leslie, Bauman and Sallis (2004) categorise three types of walking, including walking for exercise, walking to get to and from places; and total walking. These types of walking had environmental attributes. Pedestrians' were encouraged to walk when pathways were aesthetically pleasing, convenient, and safe. Walkability, access to public open spaces, and proximity to amenities also encouraged pedestrians to walk. Overall, understanding environmental influences on physical activities such as walking, is important if one wishes to encourage people to walk.

Satisfaction level, is another definitive characteristic when assessing the quality of public transport services (Brons, Givoni, \& Rietveld, 2009). Evaluation of public transport user satisfaction, is also influenced by infrastructure, for example, fitted benches and cleanliness. In a study on the 'Kaohsiung Mass Rapid Transit' (KMRT) in Kaohsiung City Taiwan, a survey was conducted to collect data on perceived value, and overall user satisfaction with (KMRT) services (Lai $\&$ Chen, 2011). The results showed that factors such as service quality, perceived value, overall satisfaction and behavioural intention, had significant implications for public transit companies wishing to increase ridership; and reduce auto dependency. Vehicle safety, facility cleanliness, and customer services were also found to be key components of passenger satisfaction. A study by Efthymiou and Antoniou (2017) further clarify factors affecting user satisfaction. Comfort, staff' attitude and safety were all sighted.

Studies have shown that safe and convenient pedestrian pathways encourage walking, which in turn stimulates bus usage. However, Mitchell and 
Wee (2010) observe that motorists and motorcyclist respectively, often parked or rode on accessible pathways, creating safety concerns; and a nuisance for pedestrians. The findings have shown that the provision of safe and comfortable walking environs, alongside thoughtful motorists and appropriate road use, do increase pedestrians' 'willingness to walk' and wait at bus stops.

\section{STUDY METHODOLOGY}

Data in this study was sourced using a questionnaire, which focused on Route 303 s' bus stops. The total number of respondents targeted in this study was 400 , however, only 392 questionnaires were entirely complete and suitable for analysis. The questionnaire was divided into two parts, Part A and Part B. To qualify the respondents' socio-demographic, Part A questioned the respondents on age, gender, race, nationality, level of education, status and monthly income. In Part B, respondents were asked how far and how long it took for them to walk to the nearest bus stop. Respondents were also asked how often in the course of a month they use public bus services. Respondents were also questioned on their 'willingness to walk' if improvements to pedestrian walkways were made.

Multiple regression analysis was employed to evaluate factors that affect 'willingness to walk', such as walking time and walking distance. The dependent variable used was the respondents' 'willingness to walk' to bus stops in present and future conditions, i.e. conditions after improvements are made. The independent variables for analysis were age, gender, nationality and race, status; level of education, monthly income, vehicle ownership, license ownership and satisfaction level; frequency of bus use, distance from home to bus stop, travel time from home to bus stop, existence of pedestrian walkways and trip purpose. The multiple regression equation is shown below (1)

$$
\mathbf{Y}=\mathbf{b}_{1} \mathbf{X}_{1}+\mathbf{b}_{2} \mathbf{X}_{2}+\mathbf{b}_{3} \mathbf{X}_{3}+\ldots .+\mathbf{b}_{\mathbf{x}} \mathbf{X}_{\mathbf{x}}+\mathbf{a}
$$

$$
\begin{aligned}
& \text { Where, } \\
& Y=\text { dependent variable } \\
& \mathrm{b}=\text { regression coefficient } \\
& \mathrm{X}=\text { independent variable } \\
& \mathrm{a}=\text { constant }
\end{aligned}
$$

\section{RESULTS}

The results of the analyses show that respondents in this study were $59.7 \%$ female, and $40.3 \%$ male; and $26.3 \%$ of respondents were aged 20 to 30 . The youngest respondent was 13 years old, the most senior was 81 years of age. In total, $73.0 \%$ of respondents were Malaysian, while the other $27.0 \%$ were Indonesian, Bangladeshi, Nepalese; Indian, British and Burmese. Most respondents $(41.1 \%)$ were Malay, $36.2 \%$ were local Malay and $4.9 \%$ were 
Nur Sabahiah Abdul Sukor \& Siti Fadhlina Muhammad Fisal

Factors Influencing the Willingness to Walk to the Bus Stops in Penang Island

Indonesian Malay. The Chinese made up $19.9 \%$ of respondents, Indians accounted for $17.1 \%$, and other races, such as Kadazan and Melanau, totalled $21.9 \%$

In terms of marital status, $49.2 \%$ of respondents were married, $48.2 \%$ were single, respondents describing their status as other totalled 2.6\%. Analysis of respondents' monthly income showed $27.8 \%$ had no source of income or were dependant on their pensions, $19.1 \%$ of respondents had a monthly income of less than RM1,000, 50.1\% had a monthly income between RM1,000 and RM3,000, $2.0 \%$ had a monthly income between RM3,000 and RM5,000, and 1.0\% had a monthly income of more than RM5,000. A total of $46.2 \%$ of respondents held SPM or STPM certificates, while respondents with a higher level of education were in the minority; $7.4 \%$ held diplomas, and only $5.9 \%$ held a Bachelor, Master or $\mathrm{PhD}$. The majority (40.6\%), were educated up to secondary school level; though some did not graduate secondary school at all. Further analysis showed $45.4 \%$ of respondents were daily users of the Rapid Penang bus service, and $19.6 \%$ of respondents used the service 4 to 6 days per week. Those using the bus service less than 4 days per week totalled $14.5 \%$, those using the service only a few days per month accounted for $15.1 \%$, and respondents reporting other frequencies of use totalled $5.4 \%$.

The respondents that owned vehicles at home $(23.7 \%)$ were less than the respondents that did not own any vehicles at home (76.3\%). In detail, the respondents owned at least a car $(17.6 \%)$, a motorcycle $(9.9 \%)$ or a lorry/van $(1.0 \%)$. Moreover, most of the respondents had no driving license either for car, motorcycle or lorry/van (68.1\%) and only a few have driving licenses (31.9\%). The results can be referred in Table 1 below.

Table 1: Descriptive analysis of socio-demographics

\begin{tabular}{|c|c|c|c|c|c|}
\hline \multicolumn{2}{|l|}{ Variables } & $\mathrm{N}$ & $\%$ & Mean & $\begin{array}{l}\text { Standard } \\
\text { Deviation }\end{array}$ \\
\hline \multirow[t]{2}{*}{ Gender } & Male & 158 & 40.3 & \multirow{2}{*}{1.60} & \multirow{2}{*}{0.50} \\
\hline & Female & 234 & 59.7 & & \\
\hline \multirow[t]{7}{*}{ Age } & Under 20 & 70 & 17.9 & \multirow{7}{*}{37.89} & \multirow{7}{*}{17.20} \\
\hline & 20 to 30 & 103 & 26.3 & & \\
\hline & 30 to 40 & 64 & 16.3 & & \\
\hline & 40 to 50 & 53 & 13.5 & & \\
\hline & 50 to 60 & 55 & 14.0 & & \\
\hline & 60 to 70 & 31 & 7.9 & & \\
\hline & Above 70 & 16 & 4.1 & & \\
\hline \multirow[t]{2}{*}{ Nationality } & Malaysian & 286 & 73.0 & \multirow{2}{*}{1.27} & \multirow{2}{*}{0.45} \\
\hline & Others & 106 & 27.0 & & \\
\hline Race & Malay & 161 & 41.1 & 2.20 & 1.19 \\
\hline \multicolumn{2}{|l|}{ (C) 2018 by MIP } & 198 & & & \\
\hline
\end{tabular}


PLANNING MALAYSIA

Journal of the Malaysia Institute of Planners (2018)

\begin{tabular}{|c|c|c|c|c|c|}
\hline & Chinese & 78 & 19.9 & & \\
\hline & Indian & 67 & 17.1 & & \\
\hline & Others & 86 & 21.9 & & \\
\hline \multirow[t]{3}{*}{ Status } & Single & 189 & 48.2 & \multirow{3}{*}{1.54} & \multirow{3}{*}{0.55} \\
\hline & Married & 193 & 49.2 & & \\
\hline & Others & 10 & 2.6 & & \\
\hline \multirow[t]{5}{*}{ Income } & No Income & 109 & 27.8 & \multirow{5}{*}{2.29} & \multirow{5}{*}{0.93} \\
\hline & $<$ RM1000 & 75 & 19.1 & & \\
\hline & RM1000 - RM3000 & 196 & 50.0 & & \\
\hline & RM3000 - RM5000 & 8 & 2.0 & & \\
\hline & $>$ RM5000 & 4 & 1.0 & & \\
\hline \multirow[t]{4}{*}{ Education } & SPM/STPM/Certificate & 181 & 46.2 & \multirow{4}{*}{2.41} & \multirow{4}{*}{1.41} \\
\hline & Diploma & 29 & 7.4 & & \\
\hline & Bachelor/Master/PHD & 23 & 5.9 & & \\
\hline & Others & 159 & 40.6 & & \\
\hline Vehicle & Yes & 93 & 23.7 & \multirow{2}{*}{1.76} & \multirow{2}{*}{0.43} \\
\hline Ownership & No & 299 & 76.3 & & \\
\hline License & Yes & 125 & 31.9 & \multirow{2}{*}{1.68} & \multirow{2}{*}{0.47} \\
\hline Ownership & No & 267 & 68.1 & & \\
\hline
\end{tabular}

Table 2 shows a descriptive analysis of respondents walking distance and walking time to bus stops along Route 303 . The farthest walking distance recorded was between $200 \mathrm{~m}$ and $400 \mathrm{~m}$, reported by $37.2 \%$ of respondents. This was the same percentage recorded for respondents who walked less than $200 \mathrm{~m}$. However, $11.3 \%$ of respondents reported walking more than $1 \mathrm{~km}$ to get to a bus stop; with the most in this category being foreign workers. In addition, $47.2 \%$ of respondents reported travel times of 10 to 20 minutes to reach the nearest bus stop, and $41.1 \%$ reported travel times of less than 5 minutes.

Table 2: Descriptive analysis of walking distance (meters) and walking time (minute)

\begin{tabular}{llllll}
\hline & Variables & $\mathrm{N}$ & $\%$ & Mean & Standard Deviation \\
\hline Walking distance $(\mathrm{m})$ & $<200$ & 146 & 37.2 & & \\
& $200-400$ & 146 & 37.2 & & \\
& $400-700$ & 38 & 9.7 & 2.15 & 1.282 \\
& $700-1000$ & 18 & 4.6 & & \\
& $>1000$ & 44 & 11.3 & & \\
\hline Walking time (min) & $<5$ minutes & 161 & 41.1 & & \\
& $10-20$ minutes & 185 & 47.2 & & \\
& $20-30$ minutes & 24 & 6.1 & & \\
& $>30$ minutes & 22 & 5.6 & & \\
\hline
\end{tabular}


Nur Sabahiah Abdul Sukor \& Siti Fadhlina Muhammad Fisal

Factors Influencing the Willingness to Walk to the Bus Stops in Penang Island

In terms of questions asked regarding 'willingness to walk', Table 3 shows the comparative results between current and proposed future conditions; where future conditions assume improvements to infrastructure have been made.

Table 3: Descriptive statistic of willingness to walk based on distance and time

\begin{tabular}{|c|c|c|c|c|}
\hline \multirow[t]{2}{*}{$\begin{array}{l}\text { Infrastructure } \\
\text { Condition }\end{array}$} & \multicolumn{2}{|c|}{ Current Condition } & \multicolumn{2}{|c|}{ Future Improvement } \\
\hline & $\begin{array}{l}\text { Willingness } \\
\text { distance to } \\
\text { walk (m) }\end{array}$ & $\begin{array}{l}\text { Willingness } \\
\text { time taken to } \\
\text { walk (min) }\end{array}$ & $\begin{array}{l}\text { Willingness } \\
\text { distance to } \\
\text { walk (m) }\end{array}$ & $\begin{array}{l}\text { Willingness } \\
\text { time taken to } \\
\text { walk (min) }\end{array}$ \\
\hline Mean & 423.04 & 13.24 & 543.62 & 17.58 \\
\hline Std. Deviation & 314.150 & 10.105 & 348.449 & 11.285 \\
\hline Minimum & 50 & 3 & 50 & 5 \\
\hline Maximum & 2000 & 90 & 2000 & 90 \\
\hline
\end{tabular}

Findings based on current conditions show that the minimum distance respondents were willing to walk was $50 \mathrm{~m}$, while the maximum distance was $2 \mathrm{~km}$. The average distance walked based on current conditions was between $400 \mathrm{~m}$ to $500 \mathrm{~m}$. Respondents reported their preferred travel times as a minimum of 3 minutes, a maximum of 90 minutes, and an average time of 13 minutes. Foreign workers were found to be more amenable to longer walking distances and walking times. Findings based on future conditions, i.e. if improvements to pedestrian walkways were made, show respondents were willing to walk between $500 \mathrm{~m}$ to $600 \mathrm{~m}$. Future conditions had no bearing on the minimum and maximum distances that respondents were willing to walk. Future conditions did have a bearing on walking time, with respondents reporting extended travel times of up to 18 minutes being agreeable, if improvements to pedestrian walkways were made.

To understand factors affecting 'willingness to walk' to bus stops based on current conditions, multiple regression analysis was applied, with walking distance as the dependent variable being considered.

Table 4: Multiple regression analysis of willingness distance to walk based on current condition

\begin{tabular}{|c|c|c|c|c|c|}
\hline \multirow{2}{*}{ Model } & \multicolumn{2}{|c|}{$\begin{array}{l}\text { Unstandardized } \\
\text { Coefficients } \\
\end{array}$} & \multirow{2}{*}{$\begin{array}{l}\text { Standardized } \\
\text { Coefficients } \\
\text { Beta }\end{array}$} & \multirow{2}{*}{$\mathrm{t}$} & \multirow{2}{*}{ Sig. } \\
\hline & B & Std. Error & & & \\
\hline (Constant) & 291.486 & 82.147 & & 3.548 & .000 \\
\hline Walking Distance & 65.575 & 11.215 & .268 & 5.847 & .000 \\
\hline
\end{tabular}


PLANNING MALAYSIA

Journal of the Malaysia Institute of Planners (2018)

$\begin{array}{llllll}\text { Nationality } & -133.314 & 32.849 & -.189 & -4.058 & .000 \\ \text { Home based Trip Purpose } & -123.271 & 33.999 & -.181 & -3.626 & .000 \\ \text { Pedestrian Walkway } & 92.556 & 30.916 & .137 & 2.994 & .003 \\ \text { Status } & 73.965 & 28.535 & .118 & 2.592 & .010 \\ \text { Gender } & -63.919 & 30.017 & -.100 & -2.129 & .034\end{array}$

Dependent Variable: Willingness to walk based on current condition, \& considering distance

Table 5 shows the results of multiple regression analysis on 'willingness to walk', based on current conditions and considering travel time. Findings show that walking distance, nationality, type of trip, satisfaction level regarding pedestrian walkways; marital status and gender, are independent variables that influence 'willingness to walk'. Results indicate that respondents with longer walking times were non-Malaysian, satisfied with pathway conditions, involved with home-based trips, females; and those that are married, were also more likely to walk for a longer period of time. When analysed, both dependant variables were found to be similar.

Table 5: Multiple regression analysis of willingness to walk based on current condition \& considering time

\begin{tabular}{lllllll}
\hline \multirow{2}{*}{ Model } & \multicolumn{2}{l}{$\begin{array}{l}\text { Unstandardized } \\
\text { Coefficients }\end{array}$} & $\begin{array}{l}\text { Standardized } \\
\text { Coefficients }\end{array}$ & \multirow{2}{*}{$\mathrm{t}$} & \multirow{2}{*}{ Sig. } \\
\cline { 2 - 5 } & $\mathrm{B}$ & Std. Error & Beta & & \\
\hline (Constant) & 12.018 & 3.857 & & 3.116 & .002 \\
Walking Time & 2.081 & .582 & .165 & 3.575 & .000 \\
Nationality & -3.396 & 1.058 & -.149 & -3.208 & .001 \\
$\begin{array}{l}\text { Pedestrian } \\
\text { Walkway }\end{array}$ & 3.056 & .991 & .141 & 3.084 & .002 \\
$\begin{array}{l}\text { Status } \\
\text { Home based Trip }\end{array}$ & 3.320 & .913 & .164 & 3.635 & .000 \\
Purpose & 2.887 & 1.113 & .124 & 2.593 & .010 \\
Gender & -2.569 & .964 & -.125 & -2.666 & .008 \\
\hline
\end{tabular}

Dependent Variable: Willingness to walk based on current condition \& considering time

Respondents were asked to report what distances and travel times they would consider agreeable based on future conditions, i.e. when improvements to infrastructure were made. Table 6 shows factors affecting a respondents' 'willingness to walk', based on future conditions and considering distance. 
Nur Sabahiah Abdul Sukor \& Siti Fadhlina Muhammad Fisal

Factors Influencing the Willingness to Walk to the Bus Stops in Penang Island

Table 6: Multiple regression analysis of willingness to walk based on future conditions \& considering distance

\begin{tabular}{|c|c|c|c|c|c|}
\hline \multirow[t]{2}{*}{ Model } & \multicolumn{2}{|c|}{$\begin{array}{l}\text { Unstandardized } \\
\text { Coefficients }\end{array}$} & \multirow{2}{*}{$\begin{array}{l}\text { Standardized } \\
\text { Coefficients } \\
\text { Beta }\end{array}$} & \multirow[t]{2}{*}{$\mathrm{t}$} & \multirow[t]{2}{*}{ Sig. } \\
\hline & B & Std. Error & & & \\
\hline (Constant) & 300.655 & 91.497 & & 3.286 & .001 \\
\hline Walking Distance & 73.035 & 12.544 & .269 & 5.822 & .000 \\
\hline Nationality & -134.832 & 36.425 & -.172 & -3.702 & .000 \\
\hline $\begin{array}{l}\text { Pedestrian } \\
\text { Walkway }\end{array}$ & 113.706 & 34.206 & .152 & 3.324 & .001 \\
\hline $\begin{array}{l}\text { Home based Trip } \\
\text { Purpose }\end{array}$ & 151.284 & 38.865 & .188 & 3.893 & .000 \\
\hline Gender & -76.769 & 33.322 & -.108 & -2.304 & .022 \\
\hline
\end{tabular}

Dependent Variable: Willingness to walk based on future conditions, \& considering distance

Table 7 shows factors affecting respondents' 'willingness to walk', based on future conditions and considering time. Results show that respondents who currently walk greater distances and have longer travel times, would be willing to walk further still, and adjust to even longer travel times, if improvements to infrastructure were made.

Table 7: Multiple regression analysis of willingness to walk based on future conditions

\begin{tabular}{|c|c|c|c|c|c|}
\hline \multirow[t]{2}{*}{ Model } & \multicolumn{2}{|c|}{$\begin{array}{l}\text { Unstandardized } \\
\text { Coefficients }\end{array}$} & \multirow{2}{*}{$\begin{array}{l}\text { Standardized } \\
\text { Coefficients } \\
\text { Beta }\end{array}$} & \multirow[t]{2}{*}{$\mathrm{t}$} & \multirow[t]{2}{*}{$\mathrm{Sig}$} \\
\hline & $\mathrm{B}$ & Std. Error & & & \\
\hline (Constant) & 12.867 & 3.980 & & 3.233 & .001 \\
\hline Walking Time & 2.845 & .668 & .202 & 4.257 & .000 \\
\hline $\begin{array}{l}\text { Pedestrian } \\
\text { Walkway }\end{array}$ & 4.165 & 1.136 & .171 & 3.666 & .000 \\
\hline Nationality & -3.208 & 1.193 & -.126 & -2.688 & .007 \\
\hline $\begin{array}{l}\text { Home based Trip } \\
\text { Purpose }\end{array}$ & 3.382 & 1.276 & .130 & 2.652 & .008 \\
\hline Gender & -2.511 & 1.100 & -.109 & -2.282 & .023 \\
\hline
\end{tabular}

Dependent Variable: Willingness to walk based on future conditions \& considering time 
PLANNING MALAYSIA

Journal of the Malaysia Institute of Planners (2018)

\section{DISCUSSION}

Collated data show respondents will walk an average distance of $600 \mathrm{~m}$ to access bus services, with the average time travelled being around 20 minutes. The farthest distance walked by respondents to access bus services was $200 \mathrm{~m}$ to $400 \mathrm{~m}$, where bus stops in areas where respondents live and work are on average only $100 \mathrm{~m}$ to $500 \mathrm{~m}$ apart.

Most respondents reported their nearest bus stop being between 10 to 20 minutes away. Respondents were willing to walk a minimum distance of $50 \mathrm{~m}$ and a maximum distance of $2,000 \mathrm{~m}$. Respondents reported their preferred travel times as a minimum of 3 minutes, a maximum of 90 minutes, and an average time of 13 minutes. Walking distance and walking times were based on actual bus stop locations. Significant factors affecting 'willingness to walk' to bus stops were comparable, whether or not improvements to infrastructure were made. Study results indicate that (gender, nationality, marital status, current walking distance, current walking time, safe and accessible pedestrian walkways, types of trip and trip purpose) all affect 'willingness to walk'. Factors that do not significantly affect 'willingness to walk' are race, level of education, monthly income, vehicle ownership, license ownership, satisfaction level, frequency of bus use and distance from home to bus stop.

\section{CONCLUSION \& RECOMMENDATIONS}

To conclude, several recommendations are made to underpin and further enhance the data obtained in this study. This research has not provided comparisons between regular and non-regular bus users. Findings have shown that regular service users would continue to use the service whether or not improvements to infrastructure were made. What this study has not shown was what effect the improvements to infrastructure may have on non-regular bus users. Thus, analysis of regular and non-regular bus users, based on future improvements should be carried out. An investigation of regular and non-regular service users' perceptions and opinions, based on current and future infrastructure is also recommended. 
Nur Sabahiah Abdul Sukor \& Siti Fadhlina Muhammad Fisal

Factors Influencing the Willingness to Walk to the Bus Stops in Penang Island

\section{ACKNOWLEDGEMENT}

This study is sponsored by the Ministry of Higher Education, Malaysia through the financial support from TRGS Grant Scheme (203/PAWAM/67610002)

\section{REFERENCES}

Brons, M., Givoni, M., \& Rietveld, P. (2009). Access to railway stations and its potential in increasing rail use. Transportation Research Part A: Policy and Practice, 43(2), 136-149.

Burke, M., \& Brown, A. L. (2007). Distances people walk for transport. Road \& Transport Research: A Journal of Australian and New Zealand Research and Practice, 16(3), 16-29.

Corpuz, G., Hay, A., \& Merom, D. (2005, September). Walking for transport and health: Trends in Sydney in the last decade. In 28th Australasian Transport Research Forum, Sydney, Australia.

Daniels, R., \& Mulley, C. (2013). Explaining walking distance to public transport: The dominance of public transport supply. Journal of Transport and Land Use, 6(2), $5-20$.

Efthymiou, D., \& Antoniou, C. (2017). Understanding the effects of economic crisis on public transport users' satisfaction and demand. Transport Policy, 53, 89-97.

Freeland, A. L., Banerjee, S. N., Dannenberg, A. L., \& Wendel, A. M. (2013). Walking associated with public transit: moving toward increased physical activity in the United States. American Journal of Public Health, 103(3), 536-542.

Google Maps (2017, April 28) Retrieved from https://www.google.com/maps/d/viewer?mid= $\quad$ ulYWzcNA05y5y6Uz1G5skv17Io\&hl=en\&ll=.5367143686190816\%2C100.311692\&z=13

Lai, W. T., \& Chen, C. F. (2011). Behavioral intentions of public transit passengers - The roles of service quality, perceived value, satisfaction and involvement. Transport Policy, 18(2), 318-325.

Mitchell, C., \& Wee, J. (2010, June). Improving Accessibility in Penang State, Malaysia. In International Conference on Mobility and Transport for Elderly and Disabled Persons (TRANSED). June 1-4, 2010, Hong Kong.

Owen, N., Humpel, N., Leslie, E., Bauman, A., \& Sallis, J. F. (2004). Understanding environmental influences on walking: review and research agenda. American Journal of Preventive Medicine, 27(1), 67-76.

Pejabat Setiausaha Kerajaan Negeri Pulau Pinang (2013). The Recommended Penang Transport Master Plan. Pulau Pinang. Retrieved from http://pgmasterplan.penang.gov.my

Penang Transport Master Plan (2017, February 22) Retrieved from http://pgmasterplan.penang.gov.my/index.php/ms/2016-02-26-03-12-57. 